\title{
Analytical Model to Predict Residual Flexural Capacity of Recycled Aggregate Concrete Beams with Corroded Longitudinal Rebars
}

\author{
Zhenghao Zou ${ }^{D},{ }^{1}$ Guojiao Yang, ${ }^{1}$ and Tian $\mathrm{Su}^{2}$ \\ ${ }^{1}$ Department of Civil Engineering, Yichun University, 576 Xuefu Load, Yichun, JiangXi, China \\ ${ }^{2}$ School of Civil and Architectural Engineering, Shandong University of Technology, 266 Xincun West Load, Zibo, \\ Shandong, China \\ Correspondence should be addressed to Zhenghao Zou; 853737475@qq.com
}

Received 2 June 2020; Revised 24 August 2020; Accepted 22 September 2020; Published 14 October 2020

Academic Editor: Giorgio Pia

Copyright (c) 2020 Zhenghao Zou et al. This is an open access article distributed under the Creative Commons Attribution License, which permits unrestricted use, distribution, and reproduction in any medium, provided the original work is properly cited.

\begin{abstract}
This paper presents the results of research on the flexural behavior of recycled aggregate concrete (RAC) beams. The correlation between flexural behavior and the corrosion level of longitudinal rebar was analysed. Based on theoretical analysis and experiment results, the influence of corrosion on flexural cracking moment was analysed and a model to predict the residual flexural capacity of RAC beams with corroded longitudinal rebars was established. The experimental results show that the development degree of cover cracks deepens with the increase of the corrosion level, and the experimental data also demonstrate that the strain distribution of concrete in the midspan of beams conforms to the plane section assumption better when the corrosion level is little but no longer satisfies the plane section assumption when the corrosion level is high.
\end{abstract}

\section{Introduction}

With the rapid development of social economy, the environmental pollution and resource consumption caused by the booming construction industry are becoming more and more prominent. In concrete projects all over the world, the amount of construction waste is huge every year. The discharge of waste concrete is the largest among all the construction waste accounting for about $30 \%-50 \%$ [1]. Such a large amount of waste concrete occupies a large amount of land, hinders the development of the city, and produces environmental pollution in the process of stacking and clearing, which brings serious environmental problems. If the current extensive model continues, the demand for building materials is expected to at least $50 \%$ by 2050 all over the world [2], and it is of great significance to recycle the waste concrete. Recycled aggregate concrete (RAC) technology is the most effective measure to solve the problem of waste concrete treatment and shortage of construction resources, and it has become a common concern of all countries in the world [3-9].

RAC beam is an important structural member, and scholars have carried out a lot of research on its shear behavior. Xiao and Lan [10], through the flexural experiment of RAC beams, showed that the results that the cracking moment of RAC beams is close to that of natural aggregate concrete (NAC) beams under the same conditions. Mahdi et al. [11] tested the flexural behavior of RAC beams, and the results show that the cracking moment of RAC beams is about 7\% lower than that of NAC beams. Yang [12] deduced the calculation method of cracking moment of RAC beams and revised the plastic influence coefficient of section resistance moment. The research results of Xiao and Lan [10], Mahdi et al. [11], and Sato et al. [13] show that the calculation model of NAC beams can be used to predict the flexural capacity of NAC beams, but the safety reserve of capacity will be reduced.

Corrosion of rebars is an important factor leading to the decline of durability of concrete structures. Corrosion of rebars can lead to premature destruction of concrete structures, and the American Society of Corrosion Engineers launched an international corrosion investigation activity impact in October 2013, and the survey was led by the American Society of corrosion engineers in conjunction with enterprises and scientific research institutions in China, Canada, India, and other countries; according to the part of 
corrosion survey invested by the Chinese Academy of Engineering, the loss and anticorrosion investment caused by corrosion in China accounted for 3.34\% of GDP in that year, and the total amount exceeded 2 trillion yuan [14]. In England and Wales, 75\% of reinforced concrete bridges are corroded by chloride ions [15].

For the structural performance, reinforcement corrosion in concrete has a marked effect on the strength and stiffness of structures [16]. The corrosion reduces cross-sectional area, steel strength, ductility, and other mechanical properties of the steel bars [17]. The corrosion products cause the expansion force of rebars that may change the stress state of concrete and cause it to crack and damage the concrete section. Meanwhile, the steel corrosion reduces the bond performance between corroded steel bars and concrete. Especially, after the occurrence of cracks, the restraint ability of reinforcement is reduced, also the corrosion of steel bars ribs leads to the reduction of the mechanical bite force of concrete to deformed steel bars. These factors affect the flexural capacity and failure mode of corroded reinforced concrete beams [18-20].

In recent years, scholars have carried out some experiments on the flexural behavior of RAC beams with corroded longitudinal rebars. Wang [21] and Cao [22] carried out four-point loading experiment on twelve RAC beams with different diameters and corrosion rates of longitudinal rebars. The results show that the corrosion of steel bars can significantly reduce the damage load of RAC beams. Ye et al. [23] carried out four-point loading experiment on eight RAC beams with different recycled aggregate substitution rates and strength. The results show that the flexural capacity of RAC beams calculated by the calculation method of NAC beams after considering the corrosion of rebars is in good agreement with the experimental results. Song and $\mathrm{Wu}$ [24] carried out four-point loading experiment on six RAC beams with different corrosion rates of rebars. The results show that the flexural capacity of RAC beams decreases slowly when the corrosion rate is small and decreases quickly when the corrosion rate reaches a certain value.

However, the research of flexural cracking moment has not been reported yet and the calculation model of flexural capacity of RAC beams with corroded longitudinal rebars has only reported by Wang [21]. Therefore, the flexural cracking moment and flexural capacity of RAC beams with corroded longitudinal rebars must be investigated.

In this paper, the flexural behavior experiment of RAC beams with corroded longitudinal rebars is studied. Based on results of the experiment, the flexural cracking moment of RAC beams is analysed and the calculation model to predict flexural capacity of RAC beams is established.

\section{Experimental Methods}

2.1. Materials and Mixture Proportions. The properties of the cement, fine aggregate, recycled, and natural coarse aggregate are shown in Tables 1-3. The cement used in this study was a P.O42.5 Portland cement that complies with the
TABLE 1: Cement properties.

\begin{tabular}{lc}
\hline Property & Value \\
\hline Type and class & P.O42.5 \\
Specific surface area $\left(\mathrm{m}^{2} \mathrm{~kg}^{-1}\right)$ & 372 \\
Initial and final setting times (min) & $198 / 248$ \\
Loss on ignition (\%) & 1.62 \\
3-day compressive and flexural strength $(\mathrm{MPa})$ & $5.9 / 31.5$ \\
\hline
\end{tabular}

Table 2: Properties of fine aggregate.

\begin{tabular}{lc}
\hline Property & Value \\
\hline Fineness modulus & 2.78 \\
Apparent density $\left(\mathrm{kg} \mathrm{m}^{-3}\right)$ & 2580 \\
Bulk density $\left(\mathrm{kg} \mathrm{m}^{-3}\right)$ & 1250 \\
Grain grading & $\mathrm{II}$ \\
\hline
\end{tabular}

TABle 3: Properties of coarse aggregate.

\begin{tabular}{lcc}
\hline & \multicolumn{2}{c}{ Type } \\
Property & Recycled coarse aggregate & $\begin{array}{c}\text { Natural } \\
\text { coarse } \\
\text { aggregate }\end{array}$ \\
\hline Apparent density $\left(\mathrm{kg} \mathrm{m}^{-3}\right)$ & 2390 & 2820 \\
Water absorption $(\%)$ & 5.3 & 0.8 \\
Crushing value $(\%)$ & 17.5 & 9.9 \\
Grain grading & II & II \\
\hline
\end{tabular}

Chinese standard GB 175-2007 [25]. The fine aggregate was locally available natural river sand that complies with the Chinese standard JGJ 52-2006 [26]. The recycled coarse aggregate was continuous-graded crushed gravel with a size from 5 to $31.5 \mathrm{~mm}$ complies with the Chinese standard GB 25177-2010 [27], and the natural coarse aggregate was continuous-graded crushed gravel complies with the Chinese standard JGJ 52-2006.

2.2. Casting and Curing of Concrete Beams. Eight RAC beams are cast in this experiment. The section sizes of the beams are all $120 \mathrm{~mm} \times 200 \mathrm{~mm}$, and the lengths are all $1500 \mathrm{~mm}$. Two HRB400 grade hot-rolled rebars with a diameter of $10 \mathrm{~mm}$ are arranged at the bottom of the beams. The stirrups are made of HPB300 grade bars with $6 \mathrm{~mm}$ diameter. No stirrups are installed in the middle-span section. The details of the beam are shown in Figure 1.

The concrete mixture proportion of beams is shown in Table 4. The measured yield strength of longitudinal rebar was $437.61 \mathrm{MPa}$ and the ultimate strengths was $628.45 \mathrm{MPa}$. The measured yield strength of stirrups rebars was 403.00 MPa. The concrete cubic specimens corresponding to the test beams are tested to determine the compressive strength of concrete in the day of loading experiment, and the results are also shown in Table 4 .

In order to ensure that only the longitudinal rebars are rusted during power on, insulation measures shall be taken at the joint of longitudinal reinforcement and stirrup and the joint of stirrup and erection reinforcement, as shown in Figure 2. 


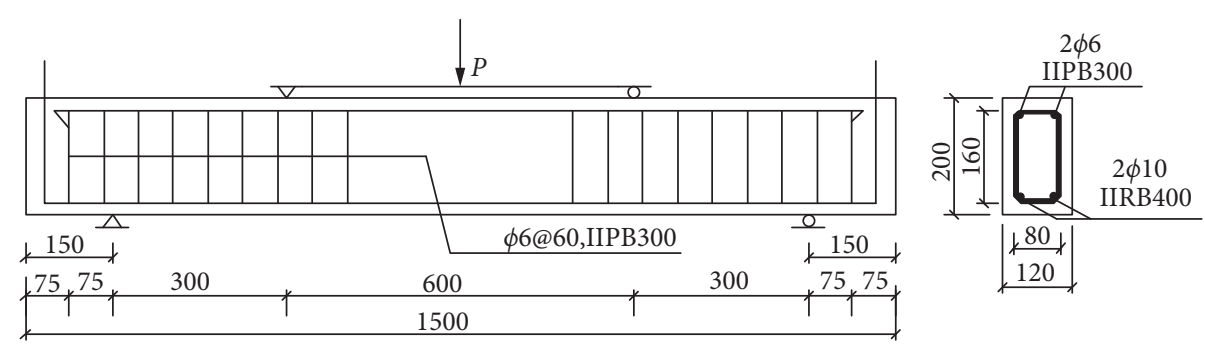

FIgURE 1: Details of beams (mm).

TABLE 4: Mixture proportions and compressive strength of the concrete $\left(\mathrm{kg} \mathrm{m}^{-3}\right)$.

\begin{tabular}{lcccccc}
\hline Number & Water-binder ratio Cement $\left(\mathrm{kg} \mathrm{m}^{-3}\right)$ & Water $\left(\mathrm{kg} \mathrm{m}^{-3}\right)$ & Gravel $\left(\mathrm{kg} \mathrm{m}^{-3}\right)$ & Sand $\left(\mathrm{kg} \mathrm{m}^{-3}\right)$ & $\begin{array}{c}\text { Compressive strength of concrete } \\
(\mathrm{MPa})\end{array}$ \\
\hline RC-F0 & 0.4 & 437.34 & 230.79 & 1109.70 & 653.53 & 34.27 \\
RC-F1 & 0.4 & 437.34 & 230.79 & 1109.70 & 653.53 & 38.06 \\
RC-F3 & 0.4 & 437.34 & 230.79 & 1109.70 & 653.53 & 33.68 \\
RC-F5 & 0.4 & 437.34 & 230.79 & 1109.70 & 653.53 & 41.91 \\
RC-F7 & 0.4 & 437.34 & 230.79 & 1109.70 & 653.53 & 45.24 \\
RC-F9 & 0.4 & 437.34 & 230.79 & 1109.70 & 653.53 & 34.34 \\
RC-F11 & 0.4 & 437.34 & 230.79 & 1109.70 & 653.53 & 39.07 \\
RC-F13 & 0.4 & 437.34 & 230.79 & 1109.70 & 653.53 & 31.60 \\
\hline
\end{tabular}

2.3. Accelerated Corrosion of Rebars. An accelerated technique was used to control corrosion process within a reasonable amount of time. The beams were immersed in 5\% $\mathrm{NaCl}$ solution after the curing. The longitudinal rebar connected with the positive pole of current source, the steel bar in immersed solution connect with the negative pole of current source, and a loop form through the $\mathrm{NaCl}$ solution and make the rebar corroded, as shown in Figure 3. The current density of $0.9 \mathrm{~mA} / \mathrm{cm}^{2}$ was selected in this experiment, and the conduction time of corrosion varied from 10.61 hours for light damage (RC-F1) to 137.94 hours for severe damage (RC-F13) according to Faraday's law, as shown in Table 5, and the target and measured corrosion level of rebar is shown in Table 5.

2.4. Loading Experiment. After accelerated corrosion of rebars, seven electrical strain gauges were used to measure the concrete strain over the depth of beams at the midspan, and electrical strain gauges were bonded to the longitudinal bars to measure the vertical strain. The arrangement of strain gauges is shown in Figure 4.

Then, all the beams were loaded in equipment, and five linear variable displacement transducers (LVDTs) with a range capacity of $100 \mathrm{~mm}$ were monitored using at midspan, loading point, and the supports of the beam. Crack widths were measured with a visual crack comparator at each load step.

\section{Results and Discussion}

3.1. Cover-cracking Caused by Corrosion. After accelerated corrosion of rebars, the cover cracks were observed and measured. Most of the cracks appeared at the bottom of beams, but also appeared at the side of beam. Figure 5 shows typical cover cracks at the bottom of corroded beams and illustrates that the development degree of cover cracks deepens with the increase of the corrosion level.

3.2. Ultimate Failure Mode. The RAC beams carried out four-point loading after equipment was checked, and the flexural-cracking force $\left(P_{\mathrm{cr}}\right)$ and ultimate force $\left(P_{\max }\right)$ measured are shown in Table 6.

Table 6 illustrates that the first flexural crack of RAC beams appears when the load added to $19 \sim 21 \mathrm{kN}$. Table 6 also illustrates that the ultimate force of RAC beams decrease with the increase of the corrosion level, the ultimate load decreases $12 \%$ when the corrosion level is $9 \%$, and $27 \%$ when the corrosion level is $12 \%$, and the corrosion has a great influence on the flexural capacity of RAC beams.

The ultimate failure mode is shown in Figure 6, and the black lines are flexural cracks, and the red lines are cover cracks at the side of the beam. Figure 6 illustrate that the distribution of cracks tends to approach the middle span with the increase of the corrosion level.

It also can be known from the experimental results that when the longitudinal rebars are not corroded, the dense cracks appear in the pure bending region, the complete oblique cracks appear in the shear-bending section, and the final failure mode of RAC beams is compression failure of concrete; when the corrosion level of longitudinal rebars is low, the distribution of cracks is sparse compared with the uncorroded beams, and the reason is that corrosion degrades the bond behavior between rebar and concrete and weakens the stress transfer between rebar and concrete, but the bond between rebar and concrete is still effective, and the final failure mode of RAC beams is still compressive failure of concrete; when the corrosion level of longitudinal rebars is high, the bond behavior between rebar and concrete which is greater degrades, and the area of rebar 


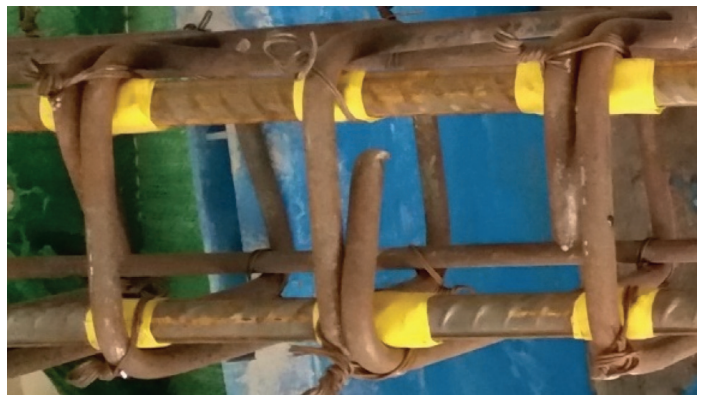

FIGURE 2: Insulation of the overlapping part of longitudinal rebar and stirrup.

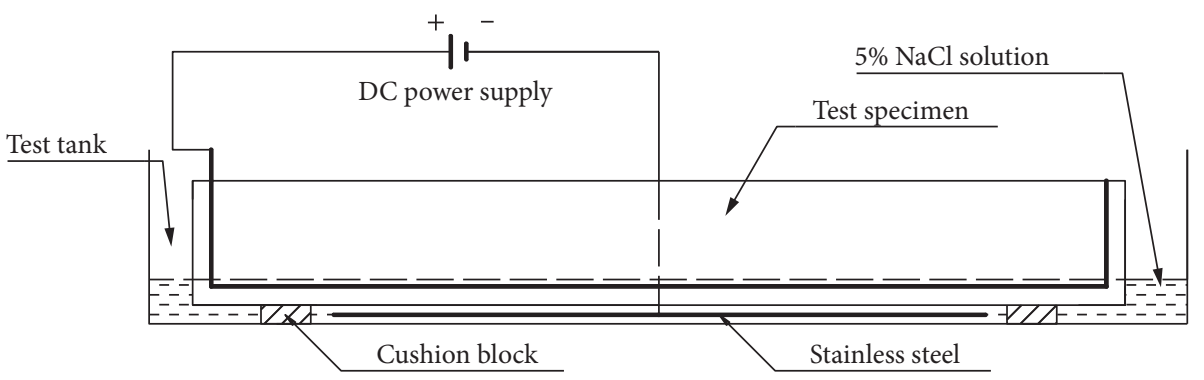

Figure 3: Accelerated corrosion of rebars.

TABLE 5: Target and measured corrosion level.

\begin{tabular}{lccc}
\hline Number & Conduction time $(\mathrm{h})$ & Target & Measured corrosion level (\%) \\
\hline RC-F0 & 0 & 0 & 0.68 \\
RC-F1 & 10.61 & 1 & 1.19 \\
RC-F3 & 31.83 & 3 & 2.51 \\
RC-F5 & 53.05 & 5 & 5.84 \\
RC-F7 & 74.27 & 7 & 5.04 \\
RC-F9 & 95.50 & 9 & 8.68 \\
RC-F11 & 116.72 & 11 & 11.90 \\
RC-F13 & 137.94 & 13 & 9.56 \\
\hline
\end{tabular}

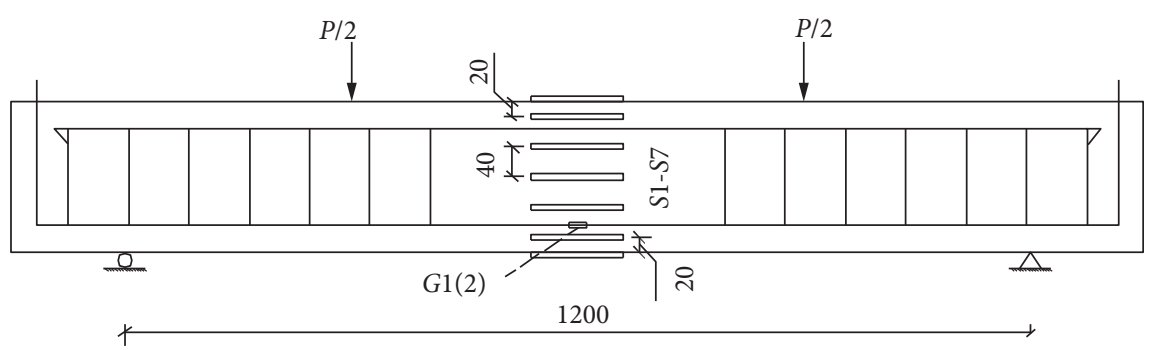

FIgURE 4: Schematic for gauges (mm).

decreases obviously; the development of cracks has changed obviously compared with the uncorroded beams, vertical cracks have become sparse, and the distribute area of cracks is close to the middle span.

3.3. Strain Distribution of Concrete in Midspan. Five representative loads are selected to read the strain values of concrete at the midspan of the beam in the loading process, and the strain distribution of concrete in the midspan under different corrosion levels is obtained, as shown in Figure 7.

Figure 7 illustrate that the strain distribution of concrete in the midspan of beams conforms to the plane section assumption better when the corrosion level is less than $5 \%$ and approximately conforms to the plane section assumption when the corrosion level is between $5 \%$ and $9 \%$. However, the strain distribution of concrete in the midspan of beams no longer satisfies the assumption when the corrosion level is higher than $9 \%$. 


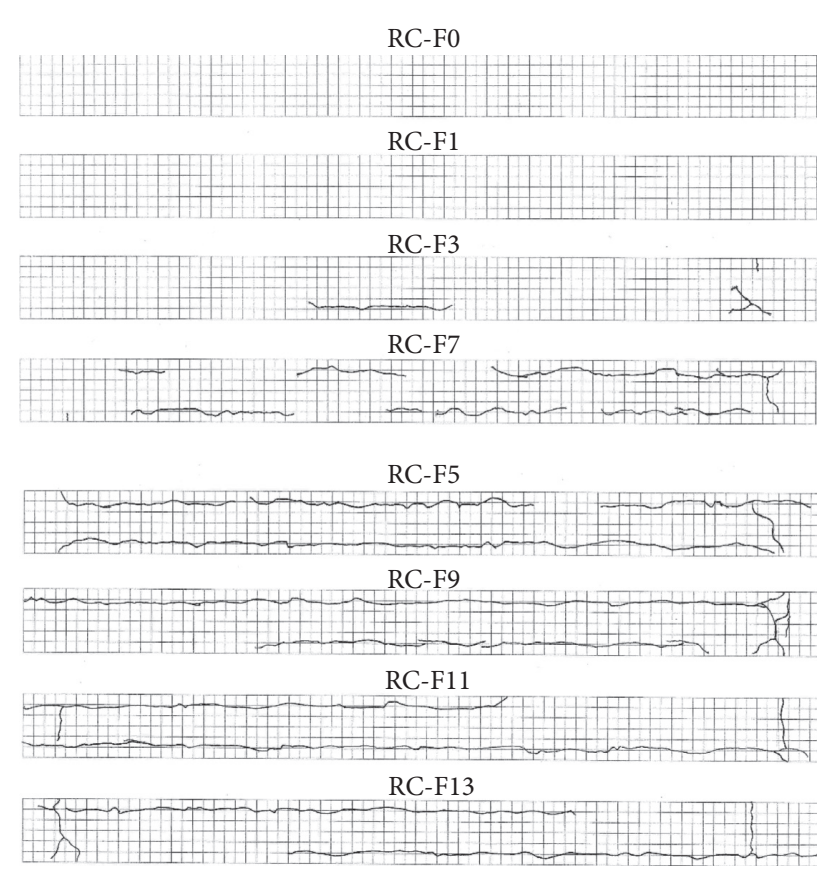

FIGURE 5: Cover cracks at the bottom of corroded RAC beams.

TABle 6: Flexural-cracking force $\left(P_{\mathrm{cr}}\right)$ and ultimate force $\left(P_{\max }\right)$.

\begin{tabular}{lccc}
\hline Number & $P_{\mathrm{cr}}(\mathrm{kN})$ & $P_{\max }(\mathrm{kN})$ & Deflection $f_{\max }(\mathrm{mm})$ \\
\hline RC-F0 & 19.1 & 103.3 & 14.89 \\
RC-F1 & 20.4 & 105.7 & 19.86 \\
RC-F3 & 21.1 & 95.3 & 15.31 \\
RC-F5 & 20.3 & 93.1 & 12.35 \\
RC-F7 & 20.1 & 96.0 & 12.18 \\
RC-F9 & 19.9 & 90.7 & 12.00 \\
RC-F11 & 20.0 & 75.8 & 5.67 \\
RC-F13 & 19.1 & 83.8 & 8.72 \\
\hline
\end{tabular}

3.4. Load-Deflection Curves. Figure 8 shows the load-deflection curves of all beams; the figure illustrates that the load-deflection curve can be divided into two stages: (1) the deflection increases linearly with the increase of the load before the yielding of the longitudinal rebars; (2) the load remains basically unchanged and the deflection increases linearly before the failure of the specimen.

\section{Analysis of Flexural Behavior of Corroded RAC Beams}

4.1. Flexural Cracking Moment. Flexural cracking moment of concrete beams is a value related to section characteristics and compressive strength of concrete. In the Chinese standard GB/T 50152-2012 [28], exploratory formula is used to calculate the flexural cracking moment of NAC beams:

$$
M_{\mathrm{cr}}=\left(\gamma W_{0}\right) f_{t}
$$

where $\gamma$ is the plastic influence coefficient of section resistance moment; $W_{0}$ is the elastic resistance moment of tension edge of section; and $f_{t}$ is the axial tensile strength of concrete.
According to the results of Yang [12], the relationship between the tensile strength, elastic modulus of recycled concrete, and the cubic compressive strength are shown as follows:

$$
\begin{aligned}
& f_{t}=0.24 f_{\mathrm{cu}}^{0.58}, \\
& E_{c}=\frac{10^{5}}{2.1+\left(63.8 / f_{\mathrm{cu}}\right)}
\end{aligned}
$$

According to equations (1) and (2), the plastic influence coefficient of section resistance moment of corroded RAC beams is assumed as $\gamma_{\mathrm{cr}}$. In this study, the flexural cracking moment of corroded RAC beams can be expressed as follows:

$$
\frac{P_{\mathrm{cr}}}{2} \times 0.3=M_{\mathrm{cr}}=\gamma_{\mathrm{cr}} W_{0} \cdot\left(0.24 f_{\mathrm{cu}}^{0.58}\right)
$$

where $f_{\mathrm{cu}}$ is the compressive strength of concrete.

According to equation (3), $\gamma_{\mathrm{cr}}$ can be expressed as equation (4). Thus, the values of $\gamma_{\mathrm{cr}}$ under different corrosion levels can be calculated by taking the measured values 


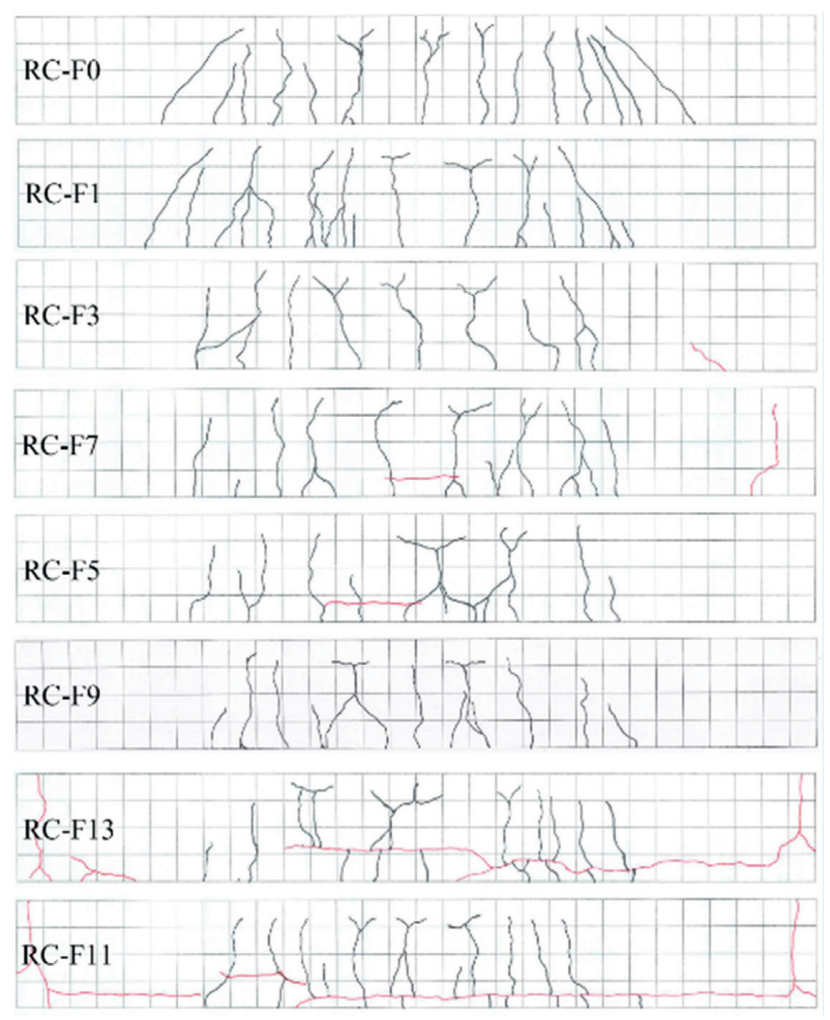

FIGURE 6: Ultimate failure mode of corroded RAC beams.

of $P_{\mathrm{cr}}$ into equation (4), and the relationship between $\gamma_{\mathrm{cr}}$ and measured corrosion levels is shown in Figure 9:

$$
\gamma_{\mathrm{cr}}=\frac{5 P_{\mathrm{cr}}}{8 W_{0} f_{\mathrm{cu}}^{0.58}},
$$

Figure 9 illustrates that the corrosion level of rebars have little effect on the plastic influence coefficient of section resistance moment and flexural cracking moment of RAC beams, and the value of $\gamma_{\mathrm{cr}}$ is 1.78 . Thus, the flexural cracking moment of corroded RAC beams can be expressed as

$$
M_{\mathrm{cr}}=0.43 W_{0} f_{\mathrm{cu}}^{0.58}
$$

To verify the applicability of equation (5), the experimental data of Ye et al. [23] are compared. The results are shown in Table 7 . The results illustrate that the validation results are relatively close. The reason for the gap is that the experimenter not only rusted the longitudinal reinforcement, but also rusted the stirrups. Fly ash was added in the process of pouring.

4.2. Measured Flexural Capacity $\left(M_{u}\right)$ of Corroded RAC Beams. The relationship between the measured flexural capacity $M_{u}$ and the corrosion levels is shown in Figure 10, and the Figure illustrates that the measured flexural capacity of RAC beams decreases with the increase of corrosion level of rebar.
4.3. New Model to Predict the Residual Flexural Capacity of Corroded RAC Beams. In this study, there are some basic assumptions for calculating the residual flexural capacity of RAC beams with corroded longitudinal rebars. (1) The section of RAC beams conforms to the plane section assumption. (2) The tensile strength of recycled concrete is not considered. (3) The constitutive relation of recycled concrete under nonuniform compression use the model of natural concrete in Chinese standard GB 50010-2010 [29], and the equivalent rectangular stress diagram coefficients of RAC beams also use the values in this standard. (4) The relationship between axial compressive strength and cubic compressive strength of recycled concrete is $f_{c}=0.76 f_{\mathrm{cu}}$.

Based on the above assumptions, the calculation method of theoretical residual flexural capacity $\left(M_{u}^{\prime}\right)$ of corroded RAC beams is shown in Figure 11, and the following formula equation (6) can be obtained from the static equilibrium condition:

$$
\begin{array}{r}
\alpha_{1} f_{c} b x=f_{y} A_{s}^{\prime}, \\
M_{\mathrm{u}}^{\prime}=\alpha_{1} f_{c} b x\left(h_{0}-\frac{x}{2}\right), \\
A_{\mathrm{s}}^{\prime}=\frac{\pi d^{2}}{2}, \\
\alpha_{1}=1,
\end{array}
$$



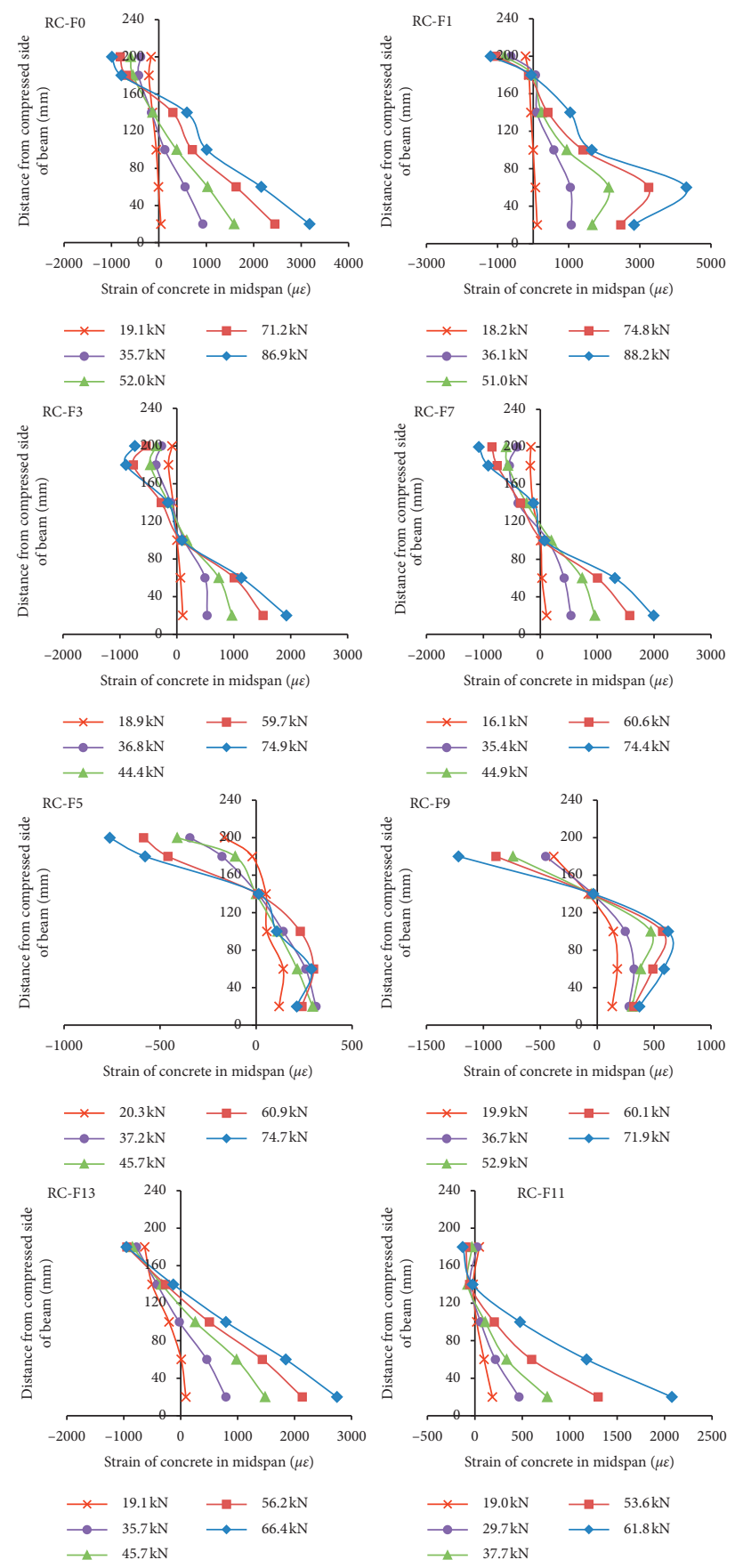

FIgURE 7: Strain distribution of concrete in the midspan.

where $M_{u}^{\prime}$ is the theoretical residual flexural capacity after corrosion and $A_{s}^{\prime}$ is the theoretical residual section area of longitudinal rebars after corrosion.

In this experiment, if the corrosion form of the longitudinal rebars is assumed as uniformly corroded, the geometric relationship of the longitudinal bars after corrosion can be expressed as follows:

$$
\frac{\pi(d / 2)^{2} \omega L}{\pi(D / 2)^{2} \omega L}=\frac{m_{L}\left(1-\rho_{L}\right)}{m_{L}}
$$

where $d$ is the diameter of longitudinal rebar after corrosion; $D$ is the diameter of longitudinal rebar before corrosion; $\omega$ is the iron density; $\rho_{L}$ is the corrosion level; and $m_{L}$ is the weight of rebar before corrosion.

According to equations (6) and (7) and basic assumptions for calculating, the theoretical formulas for calculating the residual flexural capacity of corroded RAC beams can be expressed as equation (8). Thus, the relationship between the measured flexural capacity of RAC beams and the value of theoretical residual flexural capacity calculated by equation (8) is shown in Figure 12: 


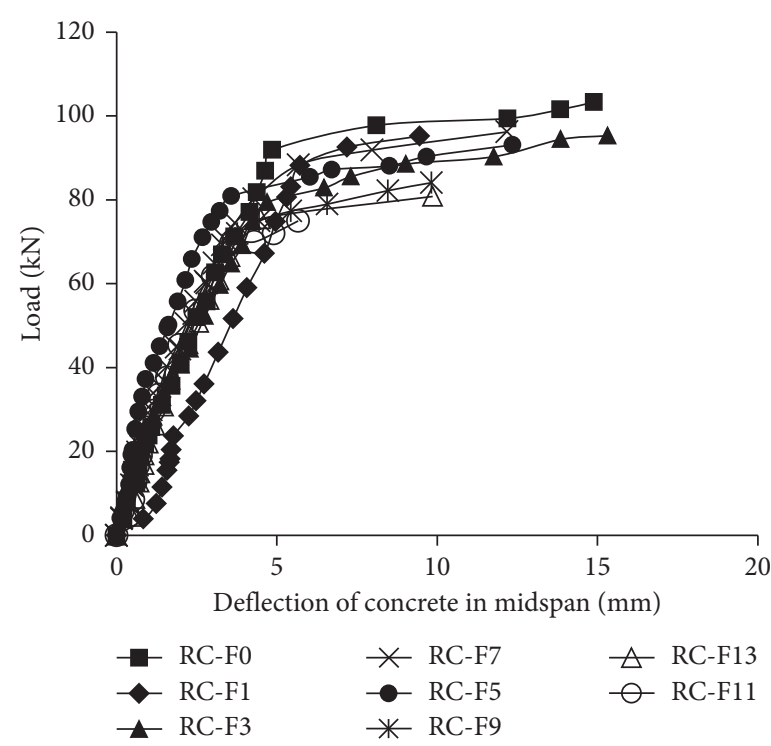

Figure 8: Load-deflection curves of RAC beams.

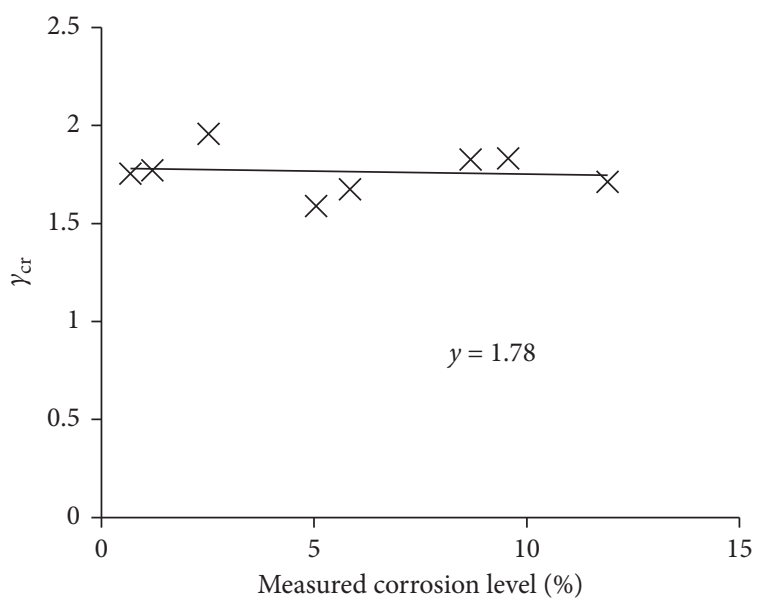

FIGURE 9: $\gamma_{c r}$ versus corrosion levels of RAC beams.

TABLE 7: Verification of the applicability of equation (5).

\begin{tabular}{lccccc}
\hline Name & $\begin{array}{c}\text { Replacement ratio } \\
(\%)\end{array}$ & Number & $\begin{array}{c}\text { Corrosion level } \\
(\%)\end{array}$ & $\begin{array}{c}\text { Measured value } \\
M_{\mathrm{cr}}^{e}(\mathrm{kN} \cdot \mathrm{m})\end{array}$ & $\begin{array}{c}\text { Calculated value } \\
M_{\mathrm{cr}}(\mathrm{kN} \cdot \mathrm{m})\end{array}$ \\
\hline Ye et al. & 100 & RCB-100 & 5.45 & 10.25 & 12.34 \\
$(2018)$ & 100 & HRCB-100 & 5.40 & 10.50 & 15.31 \\
\hline
\end{tabular}

$$
\begin{aligned}
M_{u}^{\prime} & =\frac{\pi}{2} f_{y}\left(1-\rho_{L}\right) D^{2}\left[h_{0}-\frac{\pi}{2} \cdot \frac{f_{y}}{1.52 f_{\mathrm{cu}} b} \cdot\left(1-\rho_{L}\right) D^{2}\right] \\
& =\left(1-\rho_{L}\right) f_{y} A_{s}\left[h_{0}-\frac{\left(1-\rho_{L}\right) f_{y} A_{s}}{1.52 f_{\mathrm{cu}} b}\right] .
\end{aligned}
$$

Figure 12 illustrates that the measured value is different from the theoretical value of equation (8), and the reason is the geometric relationship of corroded rebar in equation (7) is obtained under the ideal condition of uniform corrosion.
However, the corrosion of rebars cannot be uniform in actual environment, and there are pitting or noncorroded sections.

To make the theoretical value of equation (8) satisfied with the measured value, the corroded influence coefficient $\gamma_{\mathrm{L}}$ is introduced, and the fitting relationship between the theoretical value and measured value can be expressed as

$$
M_{u}=\gamma_{L} M_{u}^{\prime}
$$

According to equation (9), the relationship between the calculation value of $\gamma_{L}$ and the corrosion levels is shown in 


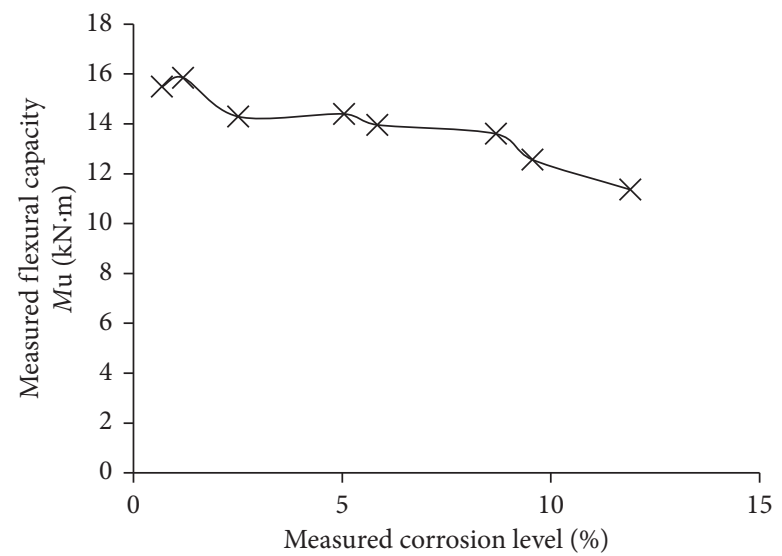

Figure 10: $M_{u}$ versus corrosion levels of RAC beams.

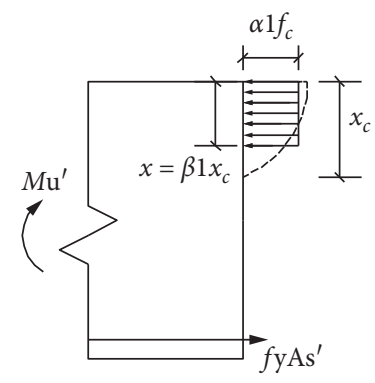

Figure 11: Calculation method of $M_{u}^{\prime}$ of RAC beams.

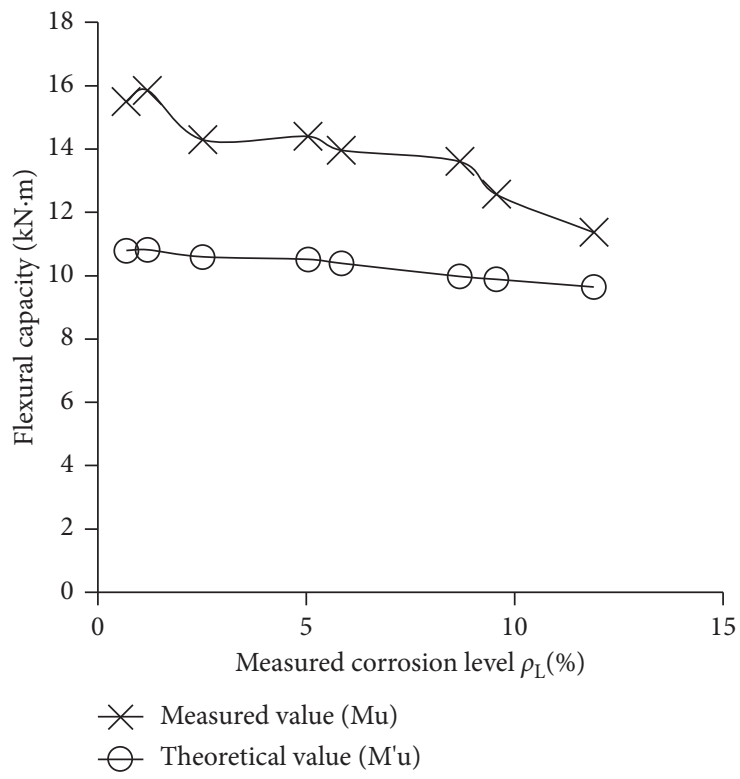

FIgURE 12: Comparison of measured and theoretical flexural capacity of RAC beams.

Figure 13, the figure illustrates that the fit degree is better. Therefore, the residual flexural capacity of corroded RAC beams can be calculated as

$$
M_{u}=\left(11.97 \rho_{L}^{3}-11.47 \rho_{L}^{2}-1.93 \rho_{L}+1.43\right) f_{y} A_{s}\left[h_{0}-\frac{\left(1-\rho_{L}\right) f_{y} A_{s}}{1.52 f_{\mathrm{cu}} b}\right] .
$$




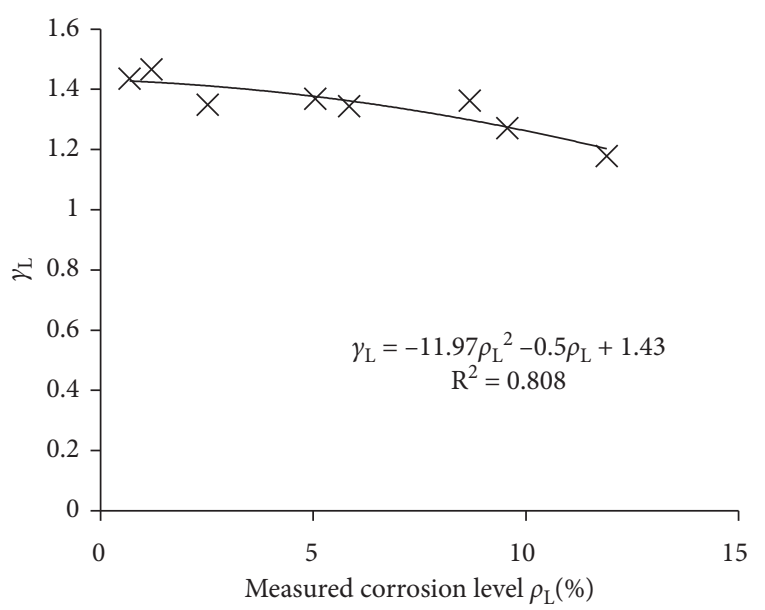

Figure 13: $\gamma_{\mathrm{L}}$ versus measured corrosion level of RAC beams.

TABLE 8: Verification of the applicability of equation (10).

\begin{tabular}{|c|c|c|c|c|c|c|c|c|}
\hline Name & Number & $\begin{array}{c}\text { Corrosion level } \rho_{\mathrm{L}} \\
(\%)\end{array}$ & $f_{y} A_{s}(\mathrm{~N})$ & $\begin{array}{c}f_{\mathrm{cu}} b \\
(\mathrm{~N} / \mathrm{mm})\end{array}$ & $\begin{array}{c}h_{0} \\
(\mathrm{~mm})\end{array}$ & $\begin{array}{c}\text { Measured value } \\
M_{u}^{e}(\mathrm{kN} \cdot \mathrm{m})\end{array}$ & $\begin{array}{l}\text { Calculated value } \\
\qquad M_{u}(\mathrm{kN} \cdot \mathrm{m})\end{array}$ & $M_{u}^{e} / M_{u}$ \\
\hline \multirow{12}{*}{$\begin{array}{l}\text { Wang } \\
\text { [21] }\end{array}$} & $\mathrm{RC} 12(1)$ & 0 & 81430.08 & 4236 & 166 & 20.53 & 17.86 & 1.15 \\
\hline & $\mathrm{RC} 12(2)$ & 2.16 & 81430.08 & 4236 & 166 & 18.68 & 17.30 & 1.08 \\
\hline & $\mathrm{RC} 12(3)$ & 4.19 & 81430.08 & 4236 & 166 & 17.34 & 16.66 & 1.04 \\
\hline & $\mathrm{RC} 12(4)$ & 6.72 & 81430.08 & 4236 & 166 & 15.43 & 15.72 & 0.98 \\
\hline & $\mathrm{RC} 12(5)$ & 9.31 & 81430.08 & 4236 & 166 & 14.53 & 14.60 & 0.99 \\
\hline & $\mathrm{RC} 12(6)$ & 13.05 & 81430.08 & 4236 & 166 & 12.92 & 12.74 & 1.01 \\
\hline & RC14(1) & 0 & 110835.39 & 4236 & 165 & 26.73 & 23.42 & 1.14 \\
\hline & $\mathrm{RC} 14(2)$ & 2.36 & 110835.39 & 4236 & 165 & 24.60 & 22.64 & 1.09 \\
\hline & $\mathrm{RC} 14(3)$ & 4.47 & 110835.39 & 4236 & 165 & 22.45 & 21.77 & 1.03 \\
\hline & $\mathrm{RC} 14(4)$ & 6.29 & 110835.39 & 4236 & 165 & 20.67 & 20.89 & 0.99 \\
\hline & $\mathrm{RC} 14(5)$ & 9.58 & 110835.39 & 4236 & 165 & 19.49 & 19.05 & 1.02 \\
\hline & $\mathrm{RC} 14(6)$ & 12.34 & 110835.39 & 4236 & 165 & 18.19 & 17.27 & 1.05 \\
\hline
\end{tabular}

To verify the applicability of equation (9), the experimental data of Wang [21] are compared. The results are shown in Table 8 , and the results illustrate that the calculated values are in good agreement with the measured value.

\section{Conclusions}

Based on the results of the experiment, the following conclusions are presented:

(1) The development degree of cover cracks deepens with the increase of the corrosion level of longitudinal rebar

(2) The ultimate force and flexural capacity of RAC beams decrease with the increase of the corrosion level of longitudinal rebar, and the corrosion has a great influence on the flexural capacity of RAC beams

(3) The strain distribution of concrete in the midspan of beams conforms to the plane section assumption better when the corrosion level is little but no longer satisfies the assumption when the corrosion level is high
(4) The corrosion level of longitudinal rebars has little effect on the flexural cracking moment of RAC beams

(5) A prediction model for the residual flexural capacity of corroded RAC beams is established based on theoretical analysis and experimental results; the results verify that the applicability of the model is better

\section{Data Availability}

All data included in this study are available from the corresponding author upon request.

\section{Conflicts of Interest}

The authors declare that there are no conflicts of interest regarding the publication of this paper.

\section{Acknowledgments}

The work carried out in this study was supported by the Postgraduate Research \& Practice Innovation Program of Jiangsu Province (Grant no. KYCX17_0272). 


\section{References}

[1] J. Z. Xiao, Recycled Concrete, China Architecture \& Building Press, Beijing, China, 2008, in Chinese.

[2] W. Lu and V. W. Y. Tam, "Construction waste management policies and their effectiveness in Hong Kong: a longitudinal review," Renewable and Sustainable Energy Reviews, vol. 23, pp. 214-223, 2013.

[3] F. Pacheco-Torgal, V. W. Y. Tam, J. A. Labrincha, Y. Ding, and J. de Brito, Handbook of Recycled Concrete and Demolition Waster, Woodhead Publishing Ltd, Cambridge, UK, 2013.

[4] T. C. Hansen, "Recycled aggregates and recycled aggregate concrete second state-of-the-art report developments 19451985," Materials and Structures, vol. 19, no. 3, pp. 201-246, 1986.

[5] T. C. Hansen, Recycling of Demolished Concrete and Masonry, E \& FN Spon, London, UK, 1992.

[6] E. K. Lauritzen, Demolition and Reuse of Concrete and Masonry. Guidelines for Demolition and Reuse of Concrete and Masonry, E \& FN Spon, London, UK, 1993.

[7] J. F. Lamond et al., "Removal and reuse of hardened concretereported by ACI committee 555," ACI Committee Reported, vol. 99, no. 3, pp. 300-325, 2002.

[8] J. de Brito and N. Saikia, Recycled Aggregate in Concrete: Use of Industrial, Construction and Demolition Waste, Springer Verlag, London, UK, 2013.

[9] J. Xiao, W. Li, Y. Fan, and X. Huang, "An overview of study on recycled aggregate concrete in China (1996-2011)," Construction and Building Materials, vol. 31, no. 6, pp. 364-383, 2012.

[10] J. Z. Xiao and Y. Lan, "Research of flexural behavior experiment of recycled aggregate concrete beams," Special Structural, vol. 23, no. 1, pp. 9-12, 2006, in Chinese.

[11] A. Mahdi, S. Adam, J. S. Volz, and K. H. Khayat, "An experimental study on flexural strength of reinforced concrete beams with $100 \%$ recycled concrete aggregate," Engineering Structures, vol. 88, no. 2, pp. 154-162, 2015.

[12] X. Yang, "Experimental study on crack resistance and crack width of normal section of recycled concrete beam," Master's thesis, Nanjing University of Aeronautics and Astronautics, Nanjing, China, 2008, in Chinese.

[13] R. Sato, I. Maruyama, T. Sogabe, and M. Sogo, "Flexural behavior of reinforced recycled concrete beams," Journal of Advanced Concrete Technology, vol. 5, no. 1, pp. 43-61, 2007.

[14] B. R. Hou, The Cost of Corrosion in China, Science Press, Beijing, China, 2019.

[15] R. K. Dhir, M. R. Jones, H. E. H. Ahmed, and A. M. G. Seneviratne, "Rapid estimation of chloride diffusion coefficient in concrete," Magazine of Concrete Research, vol. 42, no. 152, pp. 177-185, 1990.

[16] P. S. Mangat and M. S. Elgarf, "Flexural strength of concrete beams with corroding reinforcement," ACI Structural Journal, vol. 96, no. 1, pp. 149-158, 1999.

[17] Q. Wu and Y. S. Yuan, "Experimental study on the deterioration of mechanical properties of corroded steel bars," China Civil Engineering Journal, vol. 41, no. 12, pp. 42-47, 2008, in Chinese.

[18] A. Castel, R. François, and G. Arliguie, "Mechanical behaviour of corroded reinforced concrete beams-part 1: experimental study of corroded beams," Materials and Structures, vol. 33, no. 9, pp. 539-544, 2000.

[19] A. Castel, R. François, and G. Arliguie, "Mechanical behaviour of corroded reinforced concrete beams-part 2: bond and notch effects," Materials and Structures, vol. 33, no. 9, pp. 545-551, 2000.

[20] S. Coccia, S. Imperatore, and Z. Rinaldi, "Influence of corrosion on the bond strength of steel rebars in concrete," Materials and Structures, vol. 49, no. 1-2, pp. 537-551, 2016.

[21] C. X. Wang, "Study on bond slip and flexural behavior of corroded reinforced recycled aggregate concrete beams," Doctor's Thesis, Nanjing University of Aeronautics and Astronautics, Nanjing, China, 2016, in Chinese.

[22] F. B. Cao, C. X. Wang, L. G. Liu, Y. D. Xin, J. H. Li, and Z. G. Tian, "Experimental study and rigidity analysis on corroded reinforced recycled concrete beams," Building Structural, vol. 45, no. 10, pp. 49-55, 2015, in Chinese.

[23] T. Ye, W. Cao, Y. Zhang, and Z. Yang, "Flexural behavior of corroded reinforced recycled aggregate concrete beams," Advances in Materials Science and Engineering, vol. 2018, pp. 1-14, 2018.

[24] Y. J. Song and J. Wu, Experimental Research on the Flexural Properties of Corroded Reinforced Concrete Beams with Recycled Coarse Aggregates, pp. 522-527, Construction Waste Recycling \& Civil Engineering Sustainable Development, Shanghai, China, 2010.

[25] AQSIQ (General Administration of Quality Supervision, Inspection and Quarantine of the People's Republic of China), Common Portland Cements." GB 175-2007, Standards Press of China, Beijing, China, 2007, in Chinese.

[26] MC (Ministry of Construction of the People's Republic of China), "Standard for Technical Requirements and Test Method of Sand and Crushed Stone (or Gravel) for Ordinary Concrete, Standards Press of China, Beijing, China, 2006, in Chinese.

[27] AQSIQ (General Administration of Quality Supervision, Inspection and Quarantine of the People's Republic of China), "Recycled Coarse Aggregate for Concrete." GB 25177-2010, Standards Press of China, Beijing, China, 2010, in Chinese.

[28] MOHURD (Ministry of Housing and Urban-Rural Development of People's Republic of China), "Standard for Test Method of Concrete Structures." GB/T 50152-2012, Standards Press of China, Beijing, China, 2012, in Chinese.

[29] MOHURD (Ministry of Housing and Urban-Rural Development of People's Republic of China), "Code for Design of Concrete Stuctures." GB 50010-2010, Standards Press of China, Beijing, China, 2011, in Chinese. 